\title{
Analysis on the Development of Agricultural Science-technology Enterprises in Shaoxing during 2013-2015
}

\author{
Shouyu Chen \\ Zhejiang Yuexiu University of Foreign Languages, Shaoxing, P.R.China \\ chenshyu@zju.edu.cn
}

Keywords: Agriculture; Science-technology enterprise; Shaoxing city; Survey

\begin{abstract}
Based on the survey of 68 Shaoxing agricultural science-technology enterprises, we found the input factors are relatively stable in agricultural science-technology enterprises in this region, including personnel input, agricultural production base, R \& D funds and technology project etc. In terms of output of agricultural science-technology enterprises, the number of new technologies, the introduction of new varieties, patent applications and licensing, as well as access to government awards at various levels, the number of the output is also relatively stable, there is no significant increase. These results show that the development of agricultural science-technology enterprises in Shaoxing is in a stable period, and it is difficult to achieve significant growth in both input and output in the future. Government departments need to according to the status, in-depth understanding of the agricultural science-technology enterprises' situation, search the breakthrough point for the development of agricultural science-technology enterprises, for example, support some leading enterprises, then through the leading enterprises to promote the development of regional agricultural science-technology enterprises.
\end{abstract}

\section{Introduction}

With the development of economic globalization, many countries have taken measures to increase investment, reform the economic structure and promote scientific and technological actions to accelerate the development and innovation of agricultural science and technology. Agricultural science-technology enterprises play an important role in the innovation of agricultural science and technology, and they are the main drivers and executors of agricultural scientific and technological innovation. Therefore, by investigating the development status of agricultural science-technology enterprises, we can find out its advantages and disadvantages and provide the necessary factual basis for formulating relevant policies and measures scientifically. This paper will investigate the agricultural science-technology enterprises in Shaoxing, analyze the two aspects of both input and output, and reveal the development of agricultural science-technology enterprises in recent years.

\section{Data Sources}

The survey conducted by Shaoxing scientific and technologic bureau, issued questionnaires to the provincial agricultural science-technology enterprises in Shaoxing city [1][2]. The investigation of agricultural science-technology enterprises' development in the last three years (2013-2015). The questionnaires collected in this survey include 68 agricultural science and technology enterprises from four counties in Shaoxing (Keqiao, Shengzhou, Xinchang and Zhuji) (Table 1). Each enterprise has reported the relevant data in the past three years.

Table 1 Data sources

\begin{tabular}{c|c|c|c|c|c}
\hline Year\Region & Keqiao & Shengzhou & Xinchang & Zhuji & Total \\
\hline 2013 & 23 & 11 & 10 & 24 & 68 \\
\hline 2014 & 23 & 11 & 10 & 24 & 68 \\
\hline 2015 & 23 & 11 & 10 & 24 & 68 \\
\hline
\end{tabular}




\section{The Number of Input}

Personnel Input. All types of workers play a central role in the development of agricultural science-technology enterprises, and the quantity and quality of staff are directly related to the development of enterprises [3]. In recent three years, the number of workers and staff members in all areas of agricultural science-technology enterprises has increased slightly except for Shengzhou, the overall situation in other areas remains basically stable. From the proportion of the number of college degree or above, the proportion of Zhuji is slightly higher, reaching $28 \%$, and the proportion of other areas is basically stable between $19 \%-24 \%$ (Table 2 ).

Table 2 The number of employees of agricultural science-technology enterprises

\begin{tabular}{c|c|c|c|c|c|c}
\hline & \multicolumn{3}{|c|}{ Keqiao } & \multicolumn{3}{c}{ Shengzhou } \\
\cline { 2 - 7 } Year|Region & $\begin{array}{l}\text { Number of } \\
\text { employees }\end{array}$ & $\begin{array}{l}\text { College } \\
\text { degree or } \\
\text { above }\end{array}$ & $\begin{array}{l}\text { Percentage of } \\
\text { college } \\
\text { degree or } \\
\text { above }\end{array}$ & $\begin{array}{l}\text { Number } \\
\text { of } \\
\text { employees }\end{array}$ & $\begin{array}{l}\text { lollege } \\
\text { degree or } \\
\text { above }\end{array}$ & $\begin{array}{l}\text { Percentage } \\
\text { of college } \\
\text { degree or } \\
\text { above }\end{array}$ \\
\hline 2013 & 5564 & 1266 & $22.8 \%$ & 1788 & 362 & $20.2 \%$ \\
\hline 2014 & 5595 & 1315 & $23.5 \%$ & 1968 & 381 & $19.4 \%$ \\
\hline 2015 & 5336 & 1228 & $23.0 \%$ & 2084 & 403 & $19.3 \%$ \\
\hline Total & 16495 & 3809 & - & 5840 & 1146 & - \\
\hline Year|Region & $\begin{array}{l}\text { Number of } \\
\text { employees }\end{array}$ & $\begin{array}{l}\text { College } \\
\text { degree or } \\
\text { above }\end{array}$ & $\begin{array}{l}\text { Percentage of } \\
\text { college } \\
\text { degree or } \\
\text { above }\end{array}$ & $\begin{array}{l}\text { Number } \\
\text { of } \\
\text { employees }\end{array}$ & $\begin{array}{l}\text { College } \\
\text { degree or } \\
\text { above }\end{array}$ & $\begin{array}{l}\text { Percentage } \\
\text { of college } \\
\text { degree or } \\
\text { above }\end{array}$ \\
\hline 2013 & 1811 & 398 & $22.0 \%$ & 2270 & 611 & $26.9 \%$ \\
\hline 2014 & 1821 & 397 & $21.8 \%$ & 2414 & 684 & $28.3 \%$ \\
\hline 2015 & 1851 & 446 & $24.1 \%$ & 2333 & 667 & $28.6 \%$ \\
\hline Total & 5483 & 1241 & - & 7017 & 1962 & - \\
\hline
\end{tabular}

Agricultural Production Base. Agricultural production base construction is an important guarantee for agricultural production. In the past three years, the number of agricultural production bases in various regions of Shaoxing has not increased significantly. Xinchang has hardly increased in recent years, while other regions have only slightly increased (Table 3).

Table 3 The number of agricultural production base unit: $\mathrm{Mu}$

\begin{tabular}{c|c|c|c|c|c}
\hline Year\Region & Keqiao & Shengzhou & Xinchang & Zhuji & Total \\
\hline 2013 & 416468 & 8671.5 & 252053 & 170946 & 848138.5 \\
\hline 2014 & 416618 & 9471.5 & 252293 & 171480 & 849862.5 \\
\hline 2015 & 466818 & 10171.5 & 252625 & 175746 & 905360.5 \\
\hline
\end{tabular}

The Input of R \& D Funds. The technological innovation of agricultural science-technology enterprises cannot be separated from the input of R \& D funds. From the total investment in four counties of Shaoxing City, the annual R \& D investment exceeded 200 million yuan, but the investment in the past three years has not increased.

Table 4 The input of R \& D funds units: 10000 yuan

\begin{tabular}{c|c|c|c|c|c}
\hline YearlRegion & Keqiao & Shengzhou & Xinchang & Zhuji & Total \\
\hline 2013 & 9294 & 1400 & 4714 & 5447 & 20855 \\
\hline 2014 & 9091 & 1759 & 4823 & 5090 & 20763 \\
\hline 2015 & 9295 & 1518 & 5341 & 4539 & 20694 \\
\hline Total & 27680 & 4677 & 14878 & 15076 & 62311 \\
\hline
\end{tabular}


From the survey data, Shengzhou R \& D investment is significantly less than other regions, only Keqiao's 1/6, Zhuji's 1/3 (Table 4).

The Number of $R$ \& $D$ Center. $R$ \& D center, as a specialized technological innovation department within an enterprise, is an organizational guarantee for enterprises to carry out various $\mathrm{R}$ $\&$ D activities [4]. In the past three years, except for the addition of one research and development center every year in Zhuji, the rest of the region remained unchanged. This shows that the agricultural science-technology enterprises in Shaoxing have not been significantly developed in the $\mathrm{R} \& \mathrm{D}$ center of enterprises (Table 5).

Table 5 The number of $\mathrm{R} \& \mathrm{D}$ center

\begin{tabular}{c|c|c|c|c|c}
\hline Year\Region & Keqiao & Shengzhou & Xinchang & Zhuji & Total \\
\hline 2013 & 18 & 6 & 7 & 12 & 43 \\
\hline 2014 & 18 & 6 & 7 & 13 & 44 \\
\hline 2015 & 18 & 6 & 7 & 14 & 45 \\
\hline
\end{tabular}

The Number of the Scientific and Technological Plan Projects. The scientific and technological plan projects from all levels of government provide some financial support for the scientific and technological innovation of enterprises, and they are important carriers to promote the science and technology innovation in enterprises. From the survey data, in addition to the number of projects in Keqiao a slight increase every year, the rest of the region is basically declining, Xinchang and Zhuji have declined for two consecutive years, the reasons for which worth exploring (Table 6).

Table 6 The number of the scientific and technological plan projects

\begin{tabular}{c|c|c|c|c|c}
\hline Year\Region & Keqiao & Shengzhou & Xinchang & Zhuji & Total \\
\hline 2013 & 55 & 7 & 11 & 41 & 114 \\
\hline 2014 & 59 & 9 & 9 & 35 & 112 \\
\hline 2015 & 64 & 5 & 7 & 34 & 110 \\
\hline Total & 178 & 21 & 27 & 110 & 336 \\
\hline
\end{tabular}

\section{The Number of Output}

The Number of New Technology Promotion. Xinchang has some growth in the number of new technology promotion, and the other regions are basically stable every year. The number of new technologies promoted in Shengzhou is significantly less than in other regions, less than 1/7 in Zhuji (Table 7).

Table 7 The number of new technology promotion

\begin{tabular}{c|c|c|c|c|c}
\hline Year\Region & Keqiao & Shengzhou & Xinchang & Zhuji & Total \\
\hline 2013 & 24 & 3 & 13 & 29 & 69 \\
\hline 2014 & 27 & 4 & 17 & 31 & 79 \\
\hline 2015 & 25 & 4 & 21 & 29 & 79 \\
\hline Total & 76 & 11 & 51 & 89 & 227 \\
\hline
\end{tabular}

The Introduction of New Species. In the introduction of new species, Zhuji has outstanding performance, and the number of new species introduction is basically the sum of the other three counties. The four counties of Shaoxing have the rise or fall in different years, but show no obvious trend of increase (Table 8).

The Number of Patent Application and Authorization. In the past three years, the number of patent applications in Keqiao, Shengzhou and Zhuji has dropped slightly every year. The number of patent authorization in Zhuji is also declining every year, and in other counties has been increasing 
or descending in different years, and has not maintained the momentum of sustained growth (Table 9).

Table 8 The number of new species introduction

\begin{tabular}{c|c|c|c|c|c}
\hline Year\Region & Keqiao & Shengzhou & Xinchang & Zhuji & Total \\
\hline 2013 & 27 & 27 & 34 & 120 & 208 \\
\hline 2014 & 24 & 31 & 31 & 98 & 184 \\
\hline 2015 & 28 & 46 & 32 & 120 & 226 \\
\hline Total & 79 & 104 & 97 & 338 & 618 \\
\hline
\end{tabular}

Table 9 The number of patent application and authorization

\begin{tabular}{c|c|c|c|c|c|c|c|c}
\hline \multirow{2}{*}{ Year\Region } & \multicolumn{2}{|c|}{ Keqiao } & \multicolumn{2}{c|}{ Shengzhou } & \multicolumn{2}{c|}{ Xinchang } & \multicolumn{2}{c}{ Zhuji } \\
\cline { 2 - 9 } & A & B & A & B & A & B & A & B \\
\hline 2013 & 29 & 14 & 21 & 6 & 38 & 34 & 40 & 37 \\
\hline 2014 & 28 & 28 & 15 & 14 & 30 & 22 & 38 & 30 \\
\hline 2015 & 24 & 18 & 12 & 10 & 44 & 37 & 31 & 22 \\
\hline Total & 81 & 60 & 48 & 30 & 112 & 93 & 109 & 89 \\
\hline
\end{tabular}

A: Number of patent applications

B: Number of patent authorization

The Number of Awards. Zhuji has the largest number of awards annually, and the number of awards in Shengzhou is at least. The number of awards has fluctuated every year (Table 10).

Table 10 The number of awards

\begin{tabular}{c|c|c|c|c|c}
\hline Year\Region & Keqiao & Shengzhou & Xinchang & Zhuji & Total \\
\hline 2013 & 9 & 1 & 7 & 14 & 31 \\
\hline 2014 & 10 & 3 & 5 & 15 & 33 \\
\hline 2015 & 6 & 3 & 6 & 12 & 27 \\
\hline Total & 25 & 7 & 18 & 41 & 91 \\
\hline
\end{tabular}

\section{Conclusion}

In terms of personnel input, the number of workers in the enterprise is basically stable, and the proportion of employees with college degree or above is about $25 \%$, which basically meets the needs of scientific research and production. The number of agricultural production bases has been stable and no significant growth. Although the annual overall investment in research and development is higher, but in the past three years there is basically no increase, and the difference among regions is larger. The number of research centers remained unchanged, while the number of scientific and technological projects declined in recent years. In the agricultural science-technology enterprises, the number of output, for example, the promotion of new technologies, the number of new varieties introduced, the number of patent application and authorization, and the number of awards from all levels of government, are relatively stable, no significant increase. The above survey results show that the development of agricultural science-technology enterprises in Shaoxing is in a stable period, and it is difficult to achieve significant growth in input and output in the future. Government departments need to according to the situation, in-depth understanding of the actual agricultural science-technology enterprises, then explore the breakthrough point for the development of agricultural science-technology enterprises, for example, support a number of leading enterprises, through these leading enterprises to promote the development of agricultural science-technology enterprises in the region [5] 


\section{References}

[1] Fowler Jr F J. Survey research methods. Sage Publications, 2013.

[2] Wilson E, Campain R, Moore $M$, et al. An accessible survey method: Increasing the participation of people with a disability in large sample social research. Telecommunications Journal of Australia, 2013, 63(2).

[3] Borman W C, Motowidlo S J. Task performance and contextual performance: The meaning for personnel selection research. Human Performance, 1997, 10(2): 99-109.

[4] Francis J, Mytalka L, van Huis A, et al. Innovation Systems: towards effective strategies in support of smallholder farmers. CTA, 2016.

[5] Xu X, Li X, Qi G, et al. Science, technology, and the politics of knowledge: The case of China's agricultural technology demonstration centers in Africa. World Development, 2016, 81: 82-91. 